\title{
Influence of Re-Greening on the Infiltrability of Soils in South-Central Niger
}

\author{
Adamou Mahaman Moustapha ${ }^{1}$, Issoufou Baggnian1, Nazoumou Yahaya', Toudou Adam ${ }^{1}$ \\ ${ }^{1}$ Faculty of Agronomy, Abdou Moumouni University, Niamey, Niger \\ ${ }^{2}$ Faculty of Sciences and Technics, Abdou Moumouni University, Niamey, Niger \\ Email: moustapha a@yahoo.com
}

Received 28 October 2014; revised 25 November 2014; accepted 18 December 2014

Copyright (C) 2014 by authors and Scientific Research Publishing Inc.

This work is licensed under the Creative Commons Attribution International License (CC BY).

http://creativecommons.org/licenses/by/4.0/

(c) (i) Open Access

\section{Abstract}

In the Sahel, the climate and the agricultural practices are the main factors used to observe regreening process. But the extension of this re-greening is not uniform in the fields, so we can assume that there are other factors contributing to the greening of some areas and not others. The infiltrability of soils is considered as an important factor for these changes in the last decades. The influence of re-greening on the infiltrability of soils in the southern strip of Niger was studied through a comparison of zones according to the type of sandy soils (Uigawa/Rerey), silty-clay (Guiéza), silty-sandy (Hako) and clay-silty-sandy (Laka). The evaluated parameters are the texture, the infiltrability and the ecological characteristics (specific index of regeneration "SIR" and the Importance Value Index "IVI"). The main conclusions were: the soils of Niger South-Central are characterized by a sandy texture for more than $80 \%$. The soils which are very sandy ("Jigawa", "Rerey" and "Guieza") are more permeable and have more trees contrary to the soil Hako and Laka. Their encrusting has the tendency to reduce the vegetation cover on the soil. The infiltration measurements indicated that the rate of initial and stationary infiltration diminishes while going down towards the South. In fact, it has been recorded a rate of $123 \mathrm{~mm} / \mathrm{min}$ of initial infiltration and $87 \mathrm{~mm} / \mathrm{min}$ stationary in Dan Saga on the sandy soils against $76 \mathrm{~mm} / \mathrm{min}$ and $65 \mathrm{~mm} / \mathrm{min}$ in Daré respectively for the initial and stationary rate. Therefore, the infiltration seems to influence the density, the SIR and the IVI of the trees from the North towards the South. Some additional work is necessary in order to determine the contribution of Farmer Managed Natural Regeneration (FMNR) in the improvement of the quality of soils and the movement of water in the superficial zones of the soil.

\section{Keywords}

Infiltrability, Specific Index of Regeneration, Importance Value Index, Superficial Zones

\footnotetext{
${ }^{*}$ Corresponding author.
}

How to cite this paper: Moustapha, A.M., Baggnian, I., Yahaya, N. and Adam, T. (2014) Influence of Re-Greening on the Infiltrability of Soils in South-Central Niger. Journal of Water Resource and Protection, 6, 1731-1742. 


\section{Introduction}

The arid and semi-arid areas are characterized by a precariousness of their environmental conditions, thus making the balance of the ecosystems fragile [1]. But in the last three decades, the zone of the Sahel is presented as a rare case of success of Man's action in matters of adaptation to environmental changes [2]. In fact, the satellite images of 2003 show some important re-greening areas in the Sahel since the 1980s [3] [4]. Eklundh and Olsson [5] underlined a great increase in the normalized difference vegetation index (NDVI) on large surfaces of the Sahel and Sudan during the period from 1982 to 1999. This positive tendency was confirmed by Anyamba and Tucker [6].

The re-greening identified as an increase in the normalized difference of the index of vegetation (NDVI) [5][7] is explained by the changes in the use of lands, some practices of the management of natural resources and some agricultural practices, notably some techniques of protecting trees by Farmer Managed Natural Regeneration [8] [9].

In Niger, various studies conducted in the Southern strip of Niger (regions of Maradi and Zinder) showed that the re-greening occurred thanks to the efforts of reclaiming lands carried out by the different actors, notably the farmers thanks to the FMNR [8] [10]. Thus, the practice of the FMNR enabled to increase the number of trees on about five million hectares between 1983 and 2005 in that Southern strip [10].

Ali and Lebel [11] and Nicholson [12] showed that the dynamics of vegetation is closely linked to that of rainfalls. Thus, the rainfall stimulated the re-greening despite the serious droughts of the years 1970 and 1980 . However, the extension of re-greening not being uniform [13], some researchers such as Nemani et al. [14]; Reij and Smaling [15] assert that the strong tendency of the ongoing re-greening cannot be explained by only one factor as the climate. In fact, the density of trees is not uniform in the fields of farmers [16]. So, can the strong tendency of the ongoing re-greening be explained by the physical characteristics of the soils?

This article studies the texture and the infiltration of soils in order to understand the link between the physical characteristics of soil and re-greening for a durable use of these agricultural ecosystems.

\section{Material and Methods}

\subsection{Study Sites}

The study took place in four (4) village areas of two regions located in the South-Central of Niger: Dan Saga and El Guiéza in the region of Maradi and Daré and AraSofoua in the region of Zinder (Figure 1). The area of study is relatively populated (about 100 inhabitants $\mathrm{Km}^{-2}$ ). The climate is semi-arid, characterized by a single modal model of precipitation, with a rainy season (from June to September) and a dry season (October to May). The pluvial agriculture constitutes almost $90 \%$ of the population's activities. The crops such as millet and sorghum are mainly grown for subsistence on the sandy and poor soils, entirely depending on rainfall.

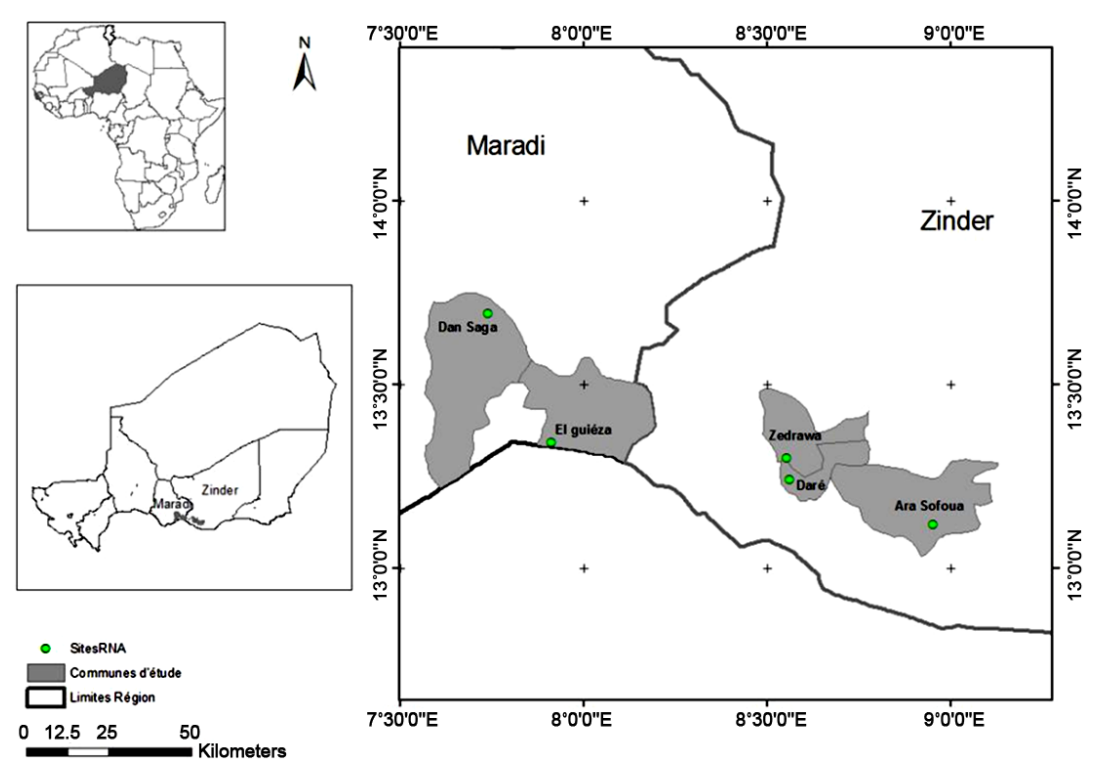

Figure 1. Location of the study sites. 


\subsection{Data Collection}

With the purpose of evaluating the contribution of texture and that of infiltration of soils in the process of regreening in these village areas, a participative approach including the farmers through the holding of meetings in the villages was adopted. In fact, a classification of soils was established by the farmers. One participant in the meeting was invited to draw on a Kraft paper a map for the repartition of the types of soils, thus giving a view on their spatial repartition. This framework presents an interest for the perception of the quality of soils [17], through which color and texture were used as main characteristics. Then, a visit to the fields was organized with four farmers chosen by the participants in the meeting in order to confirm the classification.

\subsection{Dendrometric Parameters}

The data on flora and vegetation were collected between June and July 2012 on some small squares of inventories and the plotting of the vegetation of $2000 \mathrm{~m}^{2}(50 \mathrm{~m} * 40 \mathrm{~m})$ on the various types of soil. In each plotting, an exhaustive census of ligneous was taken. Some dendrometric measurements were taken in order to evaluate the height of trees, the circumference of the basis of the trunk (CBT) at 1.30 meters. For the multicaule individuals, the clump is considered as an individual and the measurements concerned only the dominant stalk. All the individuals whose diameter is inferior to 5 centimeters are considered as juvenile zone and systematically considered as part of the regeneration [18]. The height of individuals above 2 meters was estimated by using a graduated pole and the other individuals were measured by using a tape measure. The measurements of the circumference were taken by using a soft tape measure. Because of the irregularity of the form of certain species due to anthropic pressure, the soft tape measure was used [19]. In total, the sampling was carried out on 60 small squares; that is 4 small squares per type of soil and per village area.

\subsection{Infiltration Test}

The measurements of infiltration were carried out on each square during the dry season (February) in order to neglect the impact of the tenure of the soil in initial humidity [20]. The infiltration was measured by the technic of infiltrometer with dual rings following the method described by Bouwer [21]. With a height of 20 centimeters, the rings differ by their diameter, which is 11 centimeters for the internal ring against 34 centimeters for the external one. Four measurements were taken in each type of soil and by village. The samples of soil were constituted according to the types of soil at $0-20 \mathrm{~cm}$ of depth.

\subsection{Analysis of the Soils}

The composite samples of soil coming from each site were well dried at ambient temperature, put in plastic bag, labeled and analyzed. The texture of soils was determined by the method of granulometry with five fractions according to the standard procedures of the pipette of Robinson.

\subsection{Data Analysis}

The data obtained from the plotting of infiltration, of vegetation and the analysis of soils were treated and analyzed using Microsoft Office (Excel, 2007) spreadsheet and the software XLStat 7.2.

The observed density or real density was obtained by the following formula:

$$
D o b=\frac{N}{S}
$$

where: $N$ is the total number of individuals in the sample and $S$ is the sampled surface.

The specific importance of regeneration was obtained from the ratio in percentage between the number of young plants of a species and the total number of counted young plants [22]:

$$
\operatorname{IRS}(\%)=\frac{\text { Number of young plants of a species }}{\text { Total number of counted young plants }} \times 100
$$

All the subjects whose diameter is inferior or equal to $5 \mathrm{~cm}$ were considered to belong to the regeneration [18]. The ecological importance of species was appreciated from the Importance Value Index (IVI) that enables to 
appreciate better their importance in the plant community [23]. It is a synthetic and quantified expression of the importance of a species in a plant population. This index, for a species, is defined as follows:

$$
I V I=(D o m r)+(F r)+(D r)
$$

where: Domr is the relative dominance, $\mathrm{Fr}$ is the relative frequency and $\mathrm{Dr}$ represents the relative density.

The values of Domr, Fr and Dr vary between $0 \%$ and $100 \%$ whereas those of the IVI of the species vary from 0 to $300 \%$. The species with $I V I \geq 20 \%$ are those ecologically important [24].

\section{Results}

\subsection{Classification of the Types of Soils Encountered from the Zone of Study}

The meetings at the level of each selected village point out two main groups of soil: the crusted soils or Hako and Laka; and the sandy soils locally called Jigawa and Guéza (Table 1). In fact, the division is mainly based on the texture and has two exclusive aspects (rough and fine). There is a second repartition based on the difference of color. At this level, there are four exclusive aspects (red, white, brown, black). The sandy soils have a low rate of fine elements such as silt and clay whereas the crusted soils have a high rate of more fine elements $(<0.25$ $\mathrm{mm})$.

\subsection{Physical Characteristics of the Soils of Main Study Sites}

According to the granulometric analyses (Figure 2), the soils Jigawa or Rerey and Guéza present in general, a low proportion in fine particles, compared to $95 \%$ of sand. There is no significant difference between the two types of soils. However, the rate of fine elements at the level of Hako in Dan Saga (Northern Maradi) is significantly inferior to that of the three other areas (El Guiéza, Daré and AraSofoua) (Zinder) with respectively 2\% against $10 \%$.

\subsection{Variation of the Rates of Infiltration According to the Types of Soils}

At Dan Saga (Northern Maradi), the rate of initial infiltration is 123; 126 and $72 \mathrm{~mm} / \mathrm{min}$ respectively on the Jigawa, Guéza and Hakosoils against a rate of infiltration of the stationary state of 87, 61 and $54 \mathrm{~mm} / \mathrm{min}$ respectively (Figure 3(a)). On the contrary, at El Guiéza (Southern Maradi), the rate of initial infiltration is 81; 73 and $50 \mathrm{~mm} / \mathrm{min}$ respectively on the Jigawa, Guéza and Hako soils against 64, 59 and $28 \mathrm{~mm} / \mathrm{min}$, as a rate of infiltration of the stationary state (Figure 3(a)).

The village areas of the region of Zinder are characterized by dune grounds. At Daré, the initial rate of infiltration is 76, 65 and $75 \mathrm{~mm} / \mathrm{min}$ respectively on the Rerey, Laka and Hako soils against 65, 45 and $48 \mathrm{~mm} / \mathrm{min}$, as a rate of infiltration of the stationary state (Figure 3(b)). On the contrary, at AraSofoua, the rate of initial infiltration varies 92, 81 and 2 mm/min respectively on the Rerey, Laka and Hako soils against 74, 21 and 2 mm/ min, respectively as a rate of infiltration of the stationary state.

\subsection{Ecological Importance of Ligneous Species According to the Types of Soils}

In all the sites of Rerey and Jigawa soils, the density of trees is significantly more important in relation with the

Table 1. Classification of the soils at the study sites.

\begin{tabular}{|c|c|c|c|c|}
\hline \multicolumn{3}{|c|}{ Farmer criteria } & \multicolumn{2}{|c|}{ Scientific norms } \\
\hline $\begin{array}{l}\text { Name of the } \\
\text { soils (Hausa) }\end{array}$ & Texture & Color & Classification & Texture \\
\hline Jigawa or Rérey & Sandy & Red, white or black & Not leached out ferrigineous soils & Sandy \\
\hline $\begin{array}{c}\text { Guéza ou } \\
\text { Jigawa Hako }\end{array}$ & $\begin{array}{l}\text { Superficially sandy, } \\
\text { but compacted }\end{array}$ & Red, white or black & Leached out ferrigineous soils & Silty-clayish \\
\hline Hako & Hard, very compacted & Red, brown & $\begin{array}{c}\text { Eutrophic brown soils } \\
\text { on clayish material }\end{array}$ & Silty-sandy \\
\hline Laka & $\begin{array}{l}\text { Less compacted than } \\
\text { the hako }\end{array}$ & Red, brown & Hydromorphic soils to pseudo-clay & Clayish-silty-sandy \\
\hline
\end{tabular}


Guiéza, Hako and Laka soils (Table 2). At Dan Saga, the density of trees is significantly different between the Guiéza, Hako and Laka soils whereas this difference is not significant in the areas of El Guiéza, AraSofoua and Daré.

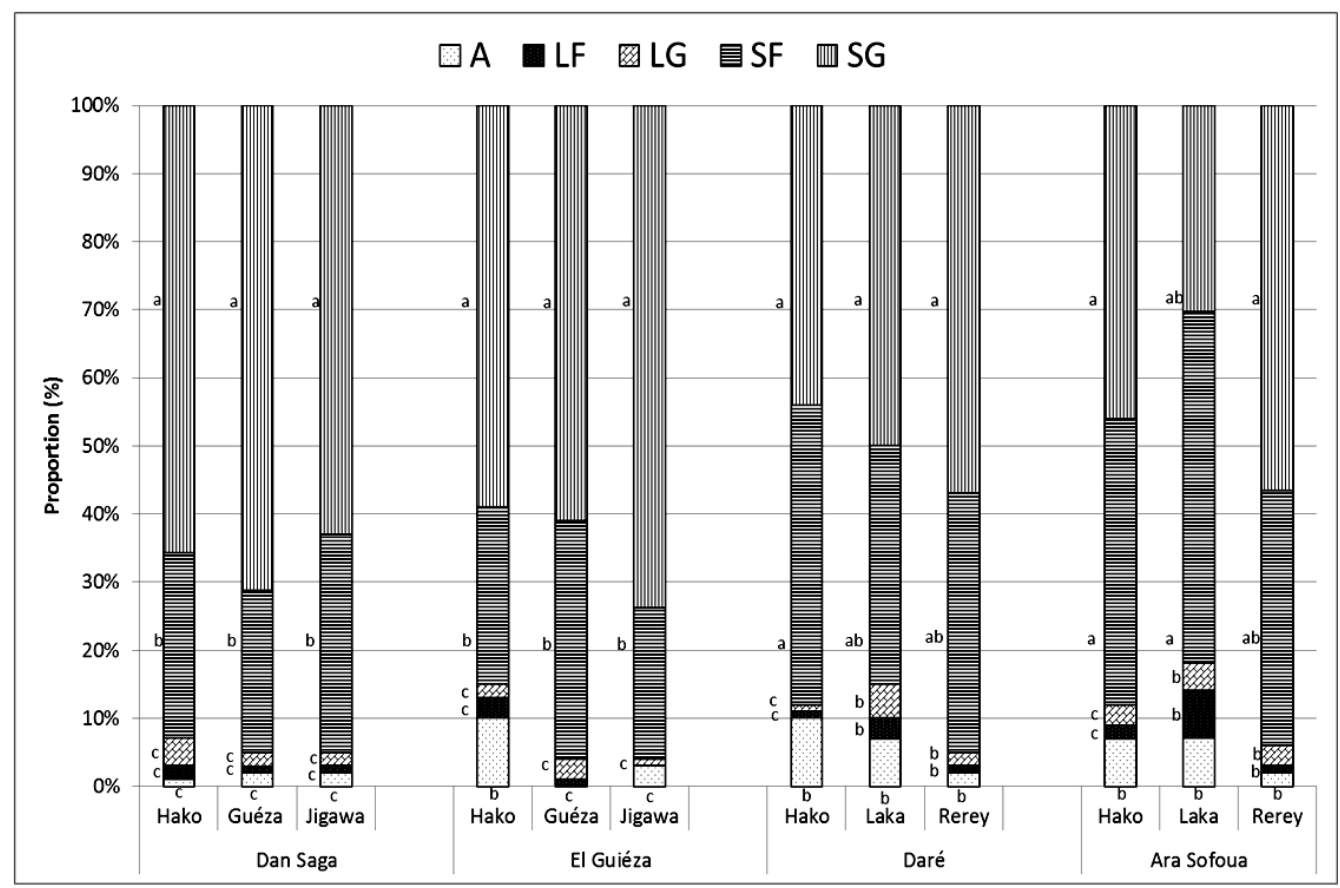

Figure 2. Average tenures in rough sands, fine sands, rough silt, fine silts and clay according to the types of soils. A: Clay; LF: Fine Silt; LG: Rough Silt; SF: Fine Sand; SG: Rough Sand.

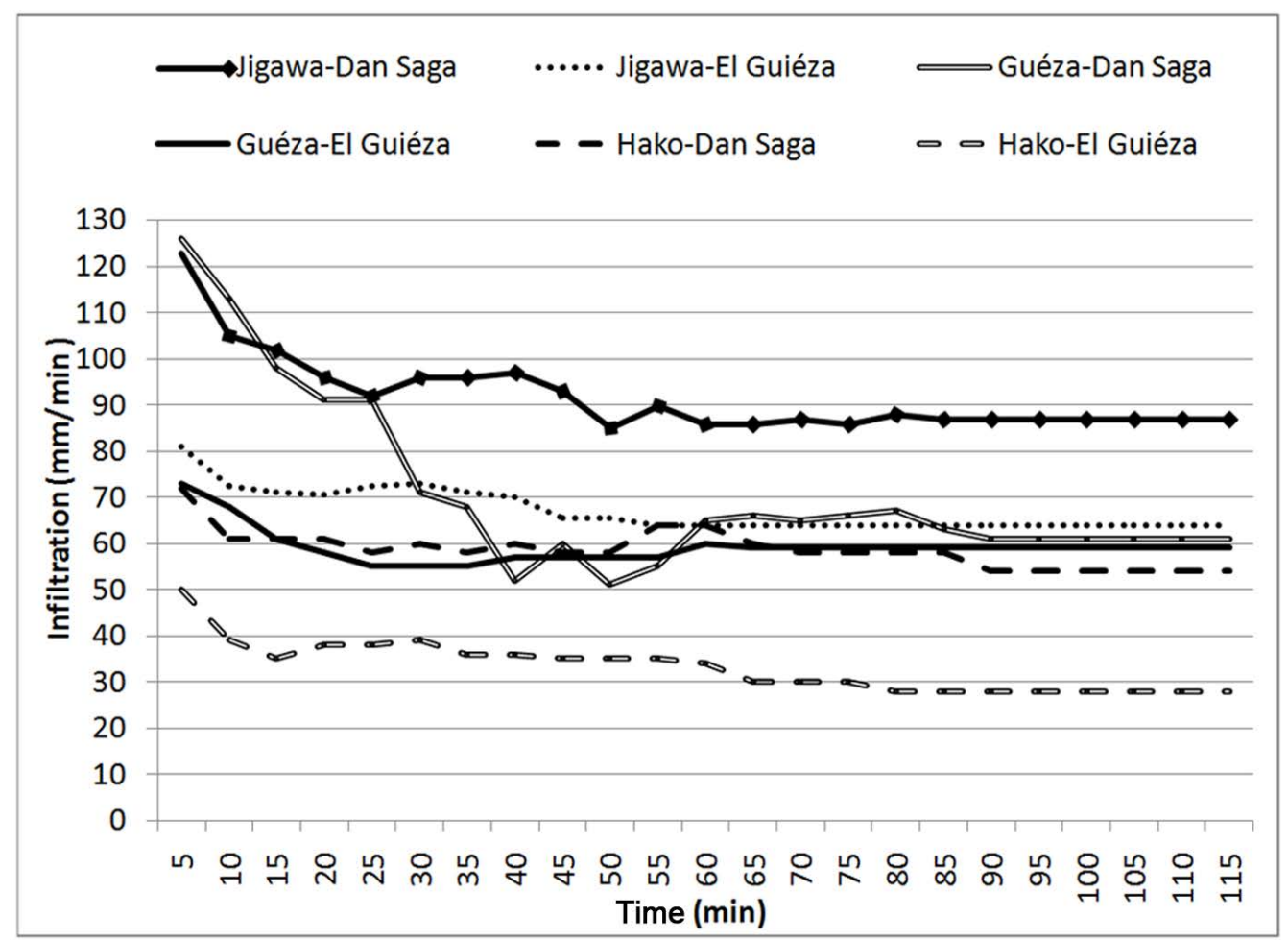

(a) 


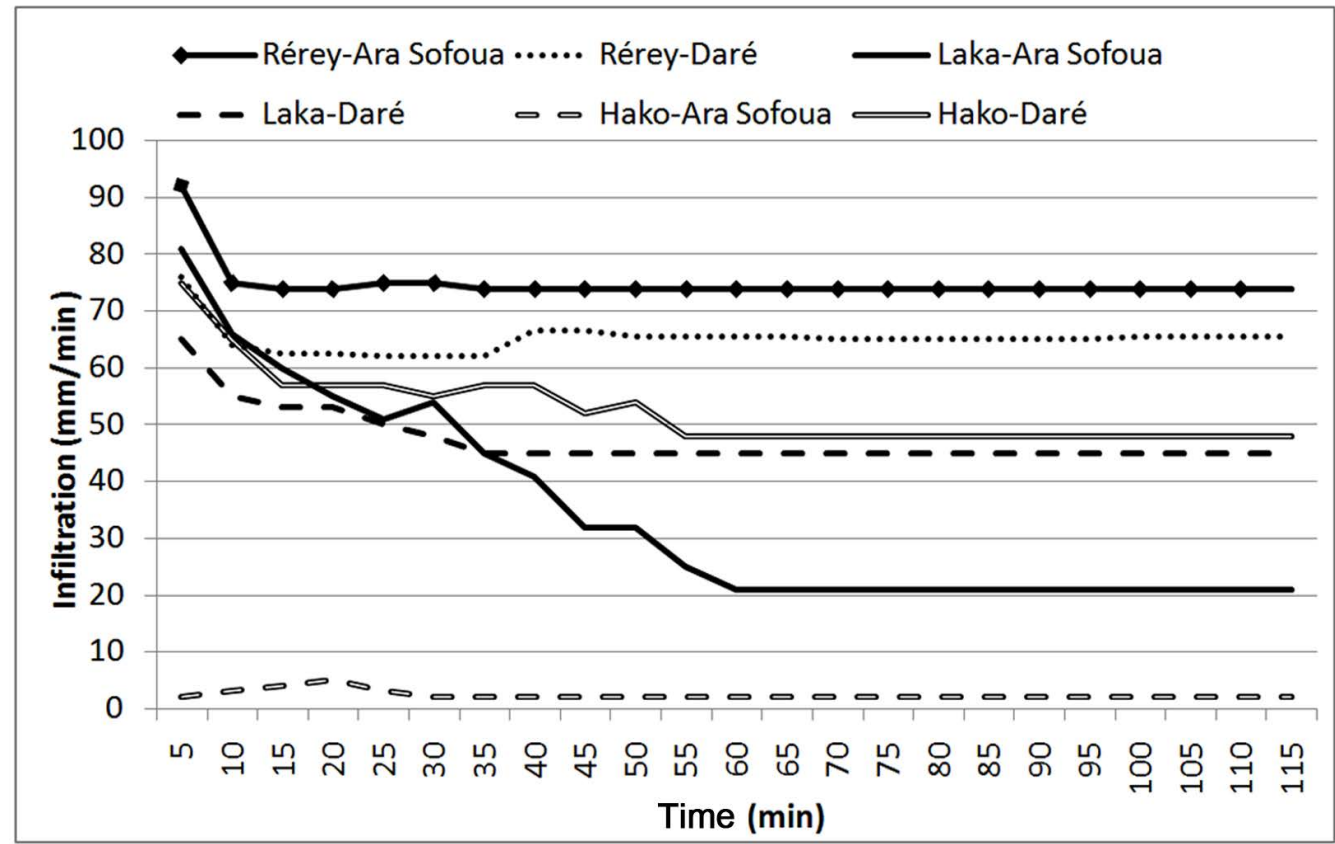

(b)

Figure 3. (a) Variation of the rates of infiltration at the sites of Dan Saga and El Guiéza (Maradi); (b) Variation of the rate of infiltration on the sites of Daré and AraSofoua (Zinder).

Table 2. Repartition of the density of the ligneous population according to the types of soils.

\begin{tabular}{|c|c|c|c|c|}
\hline Name of the species & Dan Saga (trees' $\mathrm{ha}^{-1}$ ) & El Guiéza (trees $\cdot$ ha $^{-1}$ ) & Daré (trees· $\mathrm{ha}^{-\mathbf{1}}$ ) & AraSofoua $\left(\right.$ trees $\left.\cdot \mathrm{ha}^{-1}\right)$ \\
\hline Hako/Laka & $82 \mathrm{c}$ & $73 b$ & $61 \mathrm{~b}$ & $36 b$ \\
\hline Rerey/Jigawa & $206 a$ & $151 \mathrm{a}$ & $180 \mathrm{a}$ & $84 a$ \\
\hline Guiéza & $177 b$ & $99 b$ & $98 b$ & $55 b$ \\
\hline
\end{tabular}

The averages followed by the same letter are not significantly different at the threshold of $5 \%$.

On the sites of the region of Maradi, it was taken a census of 10 ligneous species on the Hako soils against 16 on the Guiéza and Jigawa soils. $60 \%$ of the species on the Hako soils of Dan Saga have an IVI $\geq 20$. On the contrary, on the Guiéza and Jigawa soils, only 25\% of the species have an IVI $\geq 20$ (Table 3(a)). Globally, the prevailing species, that represent the highest values of ecological importance are Faidherbia albida (89.24\%) at Dan Saga on the Hako, Piliostigma reticulatum (82.65\%), El Guiéza on the Hako, Combretum glutinosum (113.32\%) in the North (Dan Saga) on the soil Guiéza, Piliostigma reticulatum (88.49\%) in the South (El Guiéza) on the Guiéza, Annona senegalensis (33.21\%), and Azadirachta indica (164.09\%) in the North on the Jigawa, Hyphaene thebaica (124.02\%) in the South on Jigawa.

The importance of regeneration according to the various species was apprehended by the calculation of the specific index of regeneration (SIR). At Dan Saga, the Pilostigma reticulatum and Annona senegalensis with 20.63\% represent the best SIR on the Hako (Table 3(b)), Combretum glutinosum (30.50\%) on the Guiéza and Azadirachta indica soils (31.25\%) on the Jigawa. At El Guiéza, it is Hyphaene thebaica that has the best potential of regeneration on the Hako, Guiéza and Jigawa with respectively a SIR of 55.22\%, 50.00\% and 81.16\%.

At Daré and AraSofoua, less than 10 ligneous species on the Hako, Rerey and Laka soils were counted. Globally, the prevailing species that represent the highest values of average ecological importance is Faidherbia albida on all the three types of soil.

The best potential of regeneration was recorded at the level of ligneous species such as Annona senegalensis, Faidherbia albida, Azadirachta indica and Piliostigma reticulatum. 
Table 3. (a) List of species according to the specific index of regeneration (SIR) and the Importance Value Index (IVI) following the types of soils in the sites of Maradi; (b) The list of species according to the specific index of regeneration (SIR) and the Importance Value Index (IVI) following the types of soils in the sites of Zinder.

(a)

\begin{tabular}{|c|c|c|c|c|c|c|}
\hline & \multicolumn{3}{|c|}{ Dan Saga } & \multicolumn{3}{|c|}{ El Guiéza } \\
\hline & Species & SIR & IVI & Species & ISR & IVI \\
\hline \multirow{11}{*}{ Hako } & Albizia chevalieri & 9.52 & 11.91 & Albizia chevalieri & & 3.74 \\
\hline & Annona senegalensis & 20.63 & 34.13 & Annona senegalensis & 1.49 & 6.45 \\
\hline & Azadirachta indica & 1.59 & 20.07 & Balanites aegyptiaca & 1.49 & 2.01 \\
\hline & Calotropis procera & 3.17 & 11.60 & Combretum glutinosum & & 7.98 \\
\hline & Cassia singueana & 4.76 & 12.76 & Faidherbia albida & 1.49 & 74.05 \\
\hline & Combretum glutinosum & 19.05 & 50.32 & Hyphaene thebaica & 55.22 & 80.61 \\
\hline & Faidherbia albida & & 89.24 & Lannea microcarpa & & 5.26 \\
\hline & Guierasene galensis & 19.05 & 28.41 & Maerua crassifolia & & 14.51 \\
\hline & Pilostigma reticulatum & 20.63 & 35.72 & Pilostigma reticulatum & 25.37 & 82.65 \\
\hline & Stereospermum kunthiam & 1.59 & 5.84 & Prosopis africana & & 2.71 \\
\hline & & & & Ziziphus mauritiana & 14.93 & 20.04 \\
\hline \multirow{16}{*}{ Guiéza } & Albizia chevalieri & 3.55 & 6.13 & Adansonia digitata & & 5.82 \\
\hline & Annona senegalensis & 8.51 & 21.76 & Albizia chevalieri & 7.69 & 14.39 \\
\hline & Azadirachta indica & 1.42 & 6.24 & Annona senegalensis & & 5.03 \\
\hline & Balanites aegyptiaca & 5.67 & 15.31 & Azadirachta indica & 7.69 & 7.81 \\
\hline & Boscia salicifolia & 1.42 & 7.60 & Balanites aegyptiaca & 3.85 & 8.96 \\
\hline & Calotropis procera & 4.26 & 6.84 & Bauhinia rufescens & & 5.82 \\
\hline & Cassia singueana & 3.55 & 6.13 & Combretum glutinosum & & 5.16 \\
\hline & Combretum glutinosum & 30.50 & 113.32 & Faidherbia albida & 3.85 & 28.58 \\
\hline & Commiphora africana & 0.71 & 3.80 & Guierasene galensis & & 5.12 \\
\hline & Faidherbia albida & & 5.30 & Hyphaene thebaica & 50.00 & 31.79 \\
\hline & Guierasene galensis & 25.53 & 34.00 & Lannea microcarpa & & 33.29 \\
\hline & Hyphaene thebaica & 1.42 & 7.60 & Maerua angolensis & 7.69 & 6.36 \\
\hline & Maerua crassifolia & 1.42 & 4.36 & Maerua crassifolia & 3.85 & 6.75 \\
\hline & Pilostigma reticulatum & 7.80 & 51.71 & Pilostigma reticulatum & 7.69 & 88.49 \\
\hline & Stereospermum kunthiam & 1.42 & 4.36 & Prosopis africana & 7.69 & 38.51 \\
\hline & Ziziphus mauritiana & 2.84 & 5.56 & Ziziphus mauritiana & & 8.12 \\
\hline \multirow{16}{*}{ Jigawa } & Adansonia digitata & 2.08 & 9.48 & Acacia nilotica & 7.25 & 17.24 \\
\hline & Annona senegalensis & & 6.19 & Balanites aegyptiaca & 4.35 & 7.89 \\
\hline & Azadirachta indica & 31.25 & 164.04 & Bauhinia rufescens & 4.35 & 7.89 \\
\hline & Balanites aegyptiaca & 12.50 & 10.62 & Combretum micranthum & 1.45 & 7.33 \\
\hline & Cassia singueana & 2.08 & 6.11 & Diospyros mespiliformis & & 6.74 \\
\hline & Combretum glutinosum & 14.58 & 29.43 & Faidherbia albida & & 94.64 \\
\hline & Commiphora africana & 2.08 & 6.11 & Hyphaene thebaica & 81.16 & 124.02 \\
\hline & Dichrosta chyscinerea & 6.25 & 7.85 & Pilostigma reticulatum & 1.45 & 27.30 \\
\hline & Faidherbia albida & 2.08 & 6.11 & Ziziphus mauritiana & & 6.94 \\
\hline & Guierasene galensis & 8.33 & 8.65 & & & \\
\hline & Hyphaene thebaica & 2.08 & 6.10 & & & \\
\hline & Lawsonia inermis & 2.08 & 6.12 & & & \\
\hline & Maerua crassifolia & 2.08 & 7.11 & & & \\
\hline & Moringa oleifera & 2.08 & 6.11 & & & \\
\hline & Pilostigma reticulatum & 6.25 & 13.06 & & & \\
\hline & Prosopis africana & 4.17 & 6.94 & & & \\
\hline
\end{tabular}


(b)

\begin{tabular}{|c|c|c|c|c|c|c|}
\hline & \multicolumn{3}{|c|}{ Daré } & \multicolumn{3}{|c|}{ AraSofoua } \\
\hline \multirow{10}{*}{ Hako } & Species & SIR & IVI & Species & ISR & IVI \\
\hline & Annona senegalensis & 48.48 & 56.27 & Commiphora africana & & 9.12 \\
\hline & Azadirachta indica & & 9.20 & Sclerocarya birrea & & 33.78 \\
\hline & Balanites aegyptiaca & 9.09 & 13.50 & Faidherbia albida & 43.75 & 117.28 \\
\hline & Commiphora africana & 6.06 & 11.20 & Annona senegalensis & 12.50 & 33.55 \\
\hline & Faidherbia albida & 21.21 & 128.78 & Pilostigma reticulatum & 12.50 & 33.99 \\
\hline & Lannea microcarpa & & 12.18 & Leptadenia pyrotechnica & 6.25 & 7.86 \\
\hline & Leptadenia hastata & 6.06 & 17.89 & Prosopis africana & 6.25 & 41.08 \\
\hline & Prosopis africana & 3.03 & 26.97 & Guierasene galensis & 12.50 & 15.58 \\
\hline & Tamarindus indica & 6.06 & 24.03 & Leptadenia hastata & 6.25 & 7.79 \\
\hline \multirow{8}{*}{ Rerey } & Annona senegalensis & 55.56 & 88.37 & Balanites aegyptiaca & & 15.98 \\
\hline & Azadirachta indica & & 20.33 & Commiphora africana & & 13.28 \\
\hline & Faidherbia albida & 2.78 & 105.19 & Faidherbia albida & 50.00 & 88.12 \\
\hline & Guierasene galensis & 30.56 & 29.48 & Annona senegalensis & 22.22 & 12.71 \\
\hline & Lannea microcarpa & & 22.51 & Pilostigma reticulatum & 16.67 & 78.55 \\
\hline & Pilostigma reticulatum & 2.78 & 15.72 & Prosopis africana & & 78.38 \\
\hline & Sclerocarya birrea & 2.78 & 8.51 & Guierasene galensis & 11.11 & 12.99 \\
\hline & Vitex doniana & 5.56 & 9.88 & & & \\
\hline \multirow{5}{*}{ Laka } & Acacia nilotica & 2.50 & 37.08 & Faidherbia albida & & 123.71 \\
\hline & Annona senegalensis & 5.00 & 24.01 & Annona senegalensis & 25.00 & 27.63 \\
\hline & Azadirachta indica & 62.50 & 168.56 & Pilostigma reticulatum & 50.00 & 87.19 \\
\hline & Eucalyptus camaldulensis & 27.50 & 58.50 & Prosopis africana & 25.00 & 51.23 \\
\hline & Guierasene galensis & 2.50 & 11.85 & Guierasene galensis & & 10.24 \\
\hline
\end{tabular}

\section{Discussion}

\subsection{Influence of the Texture of Soils}

In general, the soils of the area of study are characterized by a sandy texture for more than $80 \%$. Clay and fine silts, which ensure the role of cohesion of the different constituents of the soils, the basis of a good structure, are in low proportion. The "Jigawa" or "Rerey" soils are very sandy and very poor in fine elements and more particularly in clay. Thus, several authors [25] [26] have shown that on the sandy soils of West Africa, the putting under cultivation of lands favor the elimination of the finest elements through eluviation and water erosion and/ or wind erosion and therefore, the increase in rough sand on the surface.

For the Guéza soil on the contrary, Ambouta and Amadou [25] have pointed out its extreme sensitivity to the degradation of its physicochemical properties, thus transforming it into Jigawa soil.

\subsection{Influence of Soil Infiltration}

Infiltration is the process through which surface water penetrates in the soil. It is related to the surface outflow and that of ground water, determines the fraction of irrigation water or rain water that penetrates in the soil and therefore, affects the runoff responsible of soil erosion [27].

The results of the analysis of the infiltrability enables to notice that the soils which are very sandy ("Jigawa" 
or "Rerey" and "Guiéza") are more permeable than the Hako and laka soils. This established fact is explained by the rough and porous texture that favors rapid infiltration. The same tendency was observed by Makungo and Odiyo [28] who determined the rates of infiltration of the silty-sandy soils, sandy-clayish soils and silty-clayish soils which have some rates of initial infiltration that vary from 133.5 to $325.5 ; 71.6$ to 124.8 and 120.4 to 160.8 $\mathrm{mm} /$ hour respectively whereas the rates of infiltration of the stationary state vary from 50 to 110; 19 to 22 and 30 to $40 \mathrm{~mm} /$ hour. Agrawal et al. [29] found very significant positive correlation between the tenure in sand and the final rate of infiltration. Some similar results were also obtained by several authors [30] [31], who noticed that the speed of infiltration of the rough soil is higher than that of the soils with fine and average textures. They obtained some infiltration rates which are superior to $100 \mathrm{~mm} /$ hour and inferior to $10 \mathrm{~mm} /$ hour for the average and fine soils.

The Hako and laka soils are less permeable because of their encrusting. Hillel [32] and Talaat [33] reported that the presence of layers of clay hinders the infiltration of water because of the weakness of the macro-pores.

\subsection{Relation between Infiltration and Vegetation}

The rate of infiltration is more important on the very sandy soils ("Jigawa" or "Rerey" and "Guiéza") and they also have an important density of trees. This tendency was observed by Rao et al., [34] in the Kenyan Savanna. Lili et al. [20] showed that the presence of vegetation is positively correlated with infiltration. The positive effect of trees on infiltration is due to the formation of root channels, macro pores and micro pores. Also, the litter increases the activity of the soil's faun [35] [36]. The vegetation delays the transfer of surface water, breaks the kinetic energy of rain drops, which leads to the reduction of the effect of slaking. Also, the extension of roots, the expansion of the crown can contribute to the accumulation of organic matter and nutritive elements in the arable layer of the soil leading to a physical, chemical and biological improvement in the rhizosphere [37]. A diminution of the tenure in the organic matter in the soil diminishes the macro-porosity, which reduces the infiltration [38]. The activity of the fauna was found to be an important agent for the control of the quality of soils. The macro fauna of soil (mostly termites and ants) improve the physical properties of soil and considerably contributes to increase the infiltration of the dry season ecosystems [39]-[41].

Faidherbia albida is the species that has the best SIR and IVI in the sites of the region of Zinder. Hansson [42] has noticed the capacity of infiltration of soil under Faidherbia albida was $69 \mathrm{~mm} /$ hour in the fields in the West of Burkina Faso.

But, the success of restoration is hindered by the excessive tree felling, generally carried out by the transhumant stock breeders, debarking of trees done by certain categories of people and the overexploitation make certain species vulnerable [16] [43]. The system of leading the herd into the farming fields in Niger contributes to the diminution of the vegetable cover and the biomass and increases the runoff because of crust colonization [44]. In fact, Hiernaux et al. [45] showed that stepping and compacting are important reducing agents of soil hydrology. This combination of factors leads to the reduction of the vegetable cover, which has as consequence the development of the crusts of the soil surface [44] thus, favoring the runoff to the detriment of infiltration [44].

\section{Conclusion}

The measurement of infiltration of water in the soil is an important indication of efficiency of irrigation and drainage, the optimization of the availability of water for plants, the improvement of the yields of crops and the minimization of erosion. When the soils are crusted (Laka and Hako), the infiltration of water is slow or quasiinexistent. Also, the vegetable cover is low. As the precipitations are the main sources of water supply, ensuring the growth and production, rain water is less beneficial for the development of vegetation. But if the structure of the soil surface is improved by the work on the soil, there will be a bigger capacity of infiltration of water and the efficiency of use is improved in the long term. Other additional work is necessary in order to determine the contribution of the Farmer Managed Natural Regeneration (FMNR) in the improvement of the quality of soils and the movement of water in the superficial zones of the soil.

\section{Acknowledgements}

Authors are grateful to Issoufou Amadou, Ph.D. for his help and comments that substantially improved the article. 


\section{References}

[1] Grouzis, M. (1992) Germination et établissement des plantes annuelles sahéliennes. L'aridité une contrainte au développement, Didactique/Orstom éd, 267-282. www.documentation.ird.fr/hor/fdi:37361

[2] Polgreen, L. (2007) In Niger, Trees and Crops Turn Back the Desert. The New York Times.

[3] Hermann, S.M., Anyamba A. and Tucker, C.J. (2005) Recent Trends in Vegetation Dynamics the African Sahel and Their Relationship to Climate. Global Environmental Change, 15, 394-404. http://dx.doi.org/10.1016/j.gloenvcha.2005.08.004

[4] Olsson, L., Eklunch, L. and Ardö, J. (2005) A Recent Greening of the Sahel-Trends, Patterns and Potential Causes. Journal of Arid Environments, 63, 556-566.

[5] Eklundh, L. and Olsson, L. (2003). Vegetation Index trends for the African Sahel 1982-1999. Geophysical Research Letters, 30, 1430-1433. http://dx.doi.org/10.1029/2002GL016772

[6] Anyamba, A. and Tucker, C.J. (2005) Analysis of Sahelian Dynamics Using NOAA-AVHRR NDVI Data from 19812003. Journal of Arid Environments, 62, 596-614.

[7] Seaquist, J.W., Hickler, T., Ardö, J. and Heumann, B.W. (2009) Disentlangling the Effects of Climate and People on Sahel Vegetation Dynamics. Biogeosciences, 6, 469-477. www.biogeosciences.net/6/469/.../bg-6-469-2009.ht

[8] Larwanou, M. and Saadou, M. (2011) The Role of Human Interventions in Tree Dynamics and Environmental Rehabilitation in the Sahel Zone of Niger. Journal of Arid Environments, 75, 194-200. http://dx.doi.org/10.1016/j.jaridenv.2010.09.016

[9] Sendzimir, J., Reij, C.P. and Magnuszewski, P. (2011) Rebuilding Resilience in the Sahel: Regreening in the Maradi and Zinder Regions of Niger. Ecology and Society, 16, 1.

[10] Larwanou, M., Abdoulaye, M. and Chris, R. (2006) Etude de la Régénération Naturelle Assistée dans la Région de Zinder(Niger); une Première Exploitation d’un Phénomène Spectaculaire. International Resources Group, Washington DC. http://books.openedition.org/irdeditions/2122?lang=fr

[11] Ali, A. and Lebel, T. (2009) The Sahelian Standardized Rainfall Index Revisited. International Journal of Climatology, 29, 1705-1714. http://dx.doi.org/10.1002/joc.1832

[12] Nicholson, S.E. (2005) On the Question of the Recovery of the Rains in the West African Sahel. Journal of Arid Environments, 63, 615-641. http://www.sciencedirect.com/science/article/pii/S0140196305000509 http://dx.doi.org/10.1016/j.jaridenv.2005.03.004

[13] Eklundh, L. and Sjöström, M. (2005) Analysing Vegetation Changes in the Sahel Using Sensor Data from Landsat and NOAA. Report for the 31st International Symposium on Remote Sensing of Environment. http://www.isprs.org/publications/related/ISRSE/html/papers/669.pdf

[14] Nemani, R.R., Keeling, C.D., Hashimoto, H., Jolly, W.M., Piper, S.C., Tucker, C.J., Myneni, R.B. and Running, S.W. (2003) Climate-Driven Increase in Global Terrestrial Net Primary Production from 1982 to 1999. Science, 300, 15601563.

[15] Reij, C.P. and Smaling, E.M.A. (2005) Introduction: The Greening of the Sahel. Journal of AridEnvironments, 63, 535537.

[16] Baggnian, I., Adamou, M.M., Adam, T. and Mahamane, A. (2013) Impact du mode de gestion de la Régénération Naturelle Assistée des ligneux (RNA) sur la résilience des écosystèmes dans le centre-sud du Niger. Journal of Applied Biosciences, 71, 5742-5752. www.ajol.info/index.php/jab/article/view/98819

[17] Osunade, M.A.A. (1992) The Significance of Color in Indigenous Soil Studies. International Journal of Environmental Studies, 40, 185-193. http://dx.doi.org/10.1080/00207239208710727

[18] Mahamane, A. and Saadou, M. (2008) Méthodes d'étude et d'analyse de la flore et de la végétation tropicale. Actes de l'atelier sur l'harmonisation des méthodes. Sustainable Use of Natural Vegetationin West Africa. www.ajol.info/index.php/ijbcs/article/download/107084/96978

[19] Rondeux, J. (1999) La mesure des peuplements forestiers, Presses agronomiques de Gembloux, Gembloux. 2nd Edition.

[20] Lili, M., Bralts, V.F., Yinghua, P., Han, L. and Tingwu, L. (2008) Methods for Measuring Soil Infiltration: State of the Art. International Journal of Agricultural and Biological Engineering, 1, 22-30. www.ijabe.org/index.php/ijabe/article/download/

[21] Bouwer, H. (1986) Intake Rate. Cylinder Infiltrometer. In: Klute, A., Ed., Methods of Soil Analysis, ASA Monograph 9, ASA, Madison, 825-843.

[22] Akpo, L.E. and Grouzis, M. (1996) Influence du couvert sur la régénération de quelques espèces ligneuses sahéliennes (Nord-Sénégal, Afrique Occidentale). Webbia, 50, 247-263. www.documentation.ird.fr/hor/fdi:010014179 
http://dx.doi.org/10.1080/00837792.1996.10670605

[23] Traoré, L., Ouedraogo, I., Ouedraogo, A. and Thiombiano, A. (2011) Perceptions, usages et vulnérabilité des ressources végétales ligneuses dans le Sud-Ouest du Burkina Faso. International Journal of Biological and Chemical Sciences, 5, 258-278.

[24] Traoré, L. (2012) Influence du climat et de la protection sur la végétation ligneuse de la partie Occidentale du Burkina Faso. Thèse de Doctorat unique, Université de Ouagadougou, Ouagadougou. www.ajol.info/index.php/ijbcs/article/download/107084/96978

[25] Ambouta, J.M.K. and Amadou, I. (1996) Caractérisation des sols du terroir villageois de Gakudi et étude de l'influence des pratiques de gestion de la fertilité sur leur évolution. Rapport de synthèse CRESA. www.tropicultura.org/text/v26n3/141.pdf

[26] Casenave, A. and Valentin, C. (1989) Les états de surface de la zone sahélienne. Influence sur l’infiltration. Coll. Didactiques ORSTOM, Paris, France.

[27] Abdel Rahman, G. (2010) A Study of Infiltration Rate in South West Region of Burkina Faso. Australian Journal of Basic and Applied Sciences, 4, 1349-1357.

[28] Makungo, R. and Odiyo, J.O. (2011) Determination of Steady State Infiltration Rates for Different Soil Types in Selected Areas of Thulamela Municipality, South Africa.

[29] Agrawal, M.C., Agrawal, R.P. and Chavdhry, R.S. (1974) Infiltration Characteristic of Soil as Related to Soil Physical Properties. Journal of the Indian Society of Soil Science, 22, 285-289. www.idosi.org/wjas/wjas6(3)/15.pdf

[30] Abdel Rahman, G., Talaat, A.M. and Some, L. (2009) Sustainable Soil Water Management of the Sahel Region, North Burkina Faso. Menofia Journal of Agricultural Research, 34, 1295-1309.

[31] Gregory, J.H., Dukes, M.D., Miller, G.L. and Jones, P.H. (2005) Analysis of Double-Ring Infiltration Techniques and Development of a Simple Automatic Water Delivery System. Applied Turfgrass Science. http://dx.doi.org/10.1094/ATS-2005-0531-01-MG

[32] Hillel, D. (1971) Soil and Water, Physical Principles and Processes. Academic Press, New York.

[33] Talaat, A.M. (1991) Factors Affecting Infiltration Rate in Some Egyptian Soils. Master’s Thesis, Faculty of Agriculture, Suez Canal University, Ismaïlia.

[34] Rao, M.R., Nair, P.K.R. and Ong, C.K. (1998) Biophysical Interactions in Tropical Agroforestry Systems. Agroforestry Systems, 38, 3-50.

[35] Breman, H. and Kessler, J.J. (1995) Woody Plants in Agro-Ecosystems of Semi-Arid Regions. Springer-Verlag Berlin Heidelberg, Berlin.

[36] Giller, K.E., Nambiar, P.T.C., Srinivasa Rao, B., Dart, P.J. and Day, J.M. (1987) A Comparison of Nitrogen Fixation in Genotypes of Groundnut (Arachis hypogea L.) Using 15Nisotopedilution. Biology and Fertility of Soils, 5, 23-25. http://link.springer.com/article/10.1007\%2FBF00264341

[37] Stroosnijder, L. (1996) Modelling the Effect of Grazing on Infiltration, Runoff and Primary Production in the Sahel. Ecological Modelling, 92, 79-88. http://www.sciencedirect.com/science/article/pii/0304380095001972

[38] De Rouw, A. and Rajot, J.L. (2004) Soil Organic Matter, Surface Crusting and Erosion in Sahelian Farming Systems Based on Manuring or Fallowing. Agriculture, Ecosystems \& Environment, 104, 263-276. http://www.sciencedirect.com/science/article/pii/S0167880904000726 http://dx.doi.org/10.1016/j.agee.2003.12.020

[39] Mando, A., Stroosnijder, L. and Brussaard, L. (1996) Effects of Termites on Infiltration into Crusted Soil. Geoderman, 74, 107-113. http://www.sciencedirect.com/science/article/pii/S0016706196000584

[40] Patrice, S., Louis, S. and Daniel, T. (2007) Effects of Grazing Intensity and Prescribed Fire on Soil Physical and Hydrological Properties and Pasture Yield in the Savanna Woodlands of Burkina Faso. Agriculture, Ecosystems and Environment, 118, 80-92.

[41] Hansson, L. (2006) Comparisons of Infiltration Capacities in Different Parklands and Farming Systems of Semi-Arid Burkina Faso. Master's Thesis, Swedish University of Agricultural Sciences, Department of Forest Ecology, Uppsala. www.researchgate.net/...Parklands...agricultural.../00b

[42] Larwanou, M., Oumarou, I., Laura Snook, I., Dan guimbo, I. and Eyog-Matig, O. (2010) Pratiques sylvicoles et culturales dans les parcs agroforestiers suivant un gradient pluviométrique nord-sud dans la région de Maradi au Niger. Tropicultura, 28, 115-122. www.tropicultura.org/text/v28n2/115.pdf

[43] Casenave, A. and Valentin, C. (1992) A Runoff Capability Classification-System Based on Surface-Features Criteria in Semiarid Areas of West Africa. Journal of Hydrology, 130, 231-249. http://dx.doi.org/10.1016/0022-1694(92)90112-9 http://www.sciencedirect.com/science/article/pii/0022169492901129

[44] Hiernaux, P., Bielders, C.L., Valentin, C., Bationo, A. and Fernandez-Rivera, S. (1999) Effects of Livestock Grazing 
on Physical and Chemical Properties of Sandy Soils in Sahelian Rangelands. Journal of Arid Environment, 41, 231-245. http://www.sciencedirect.com/science/article/pii/S014019639890475X http://dx.doi.org/10.1006/jare.1998.0475

[45] Graef, F. and Stahr, K. (2000) Incidence of Soil Surface Crust Types in Semi-Arid Niger. Soil \& Tillage Research, 55, 213-218. http://www.sciencedirect.com/science/article/pii/S0167198700001173 
Scientific Research Publishing (SCIRP) is one of the largest Open Access journal publishers. It is currently publishing more than 200 open access, online, peer-reviewed journals covering a wide range of academic disciplines. SCIRP serves the worldwide academic communities and contributes to the progress and application of science with its publication.

Other selected journals from SCIRP are listed as below. Submit your manuscript to us via either submit@scirp.org or Online Submission Portal.
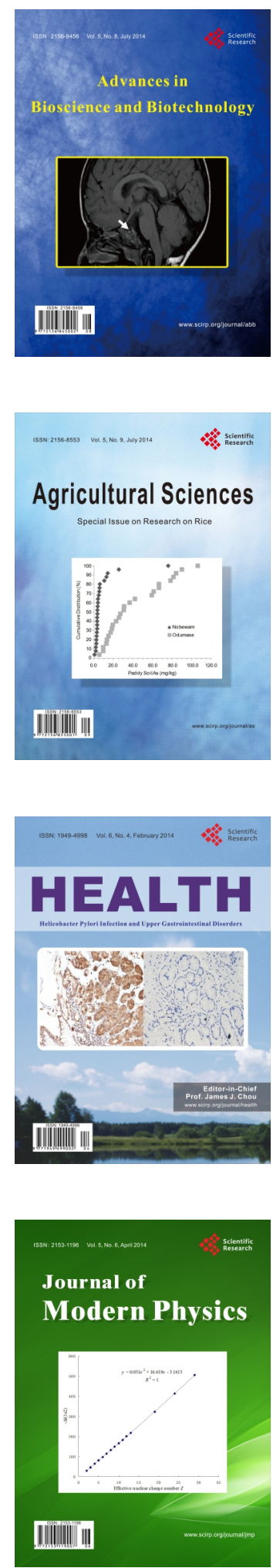
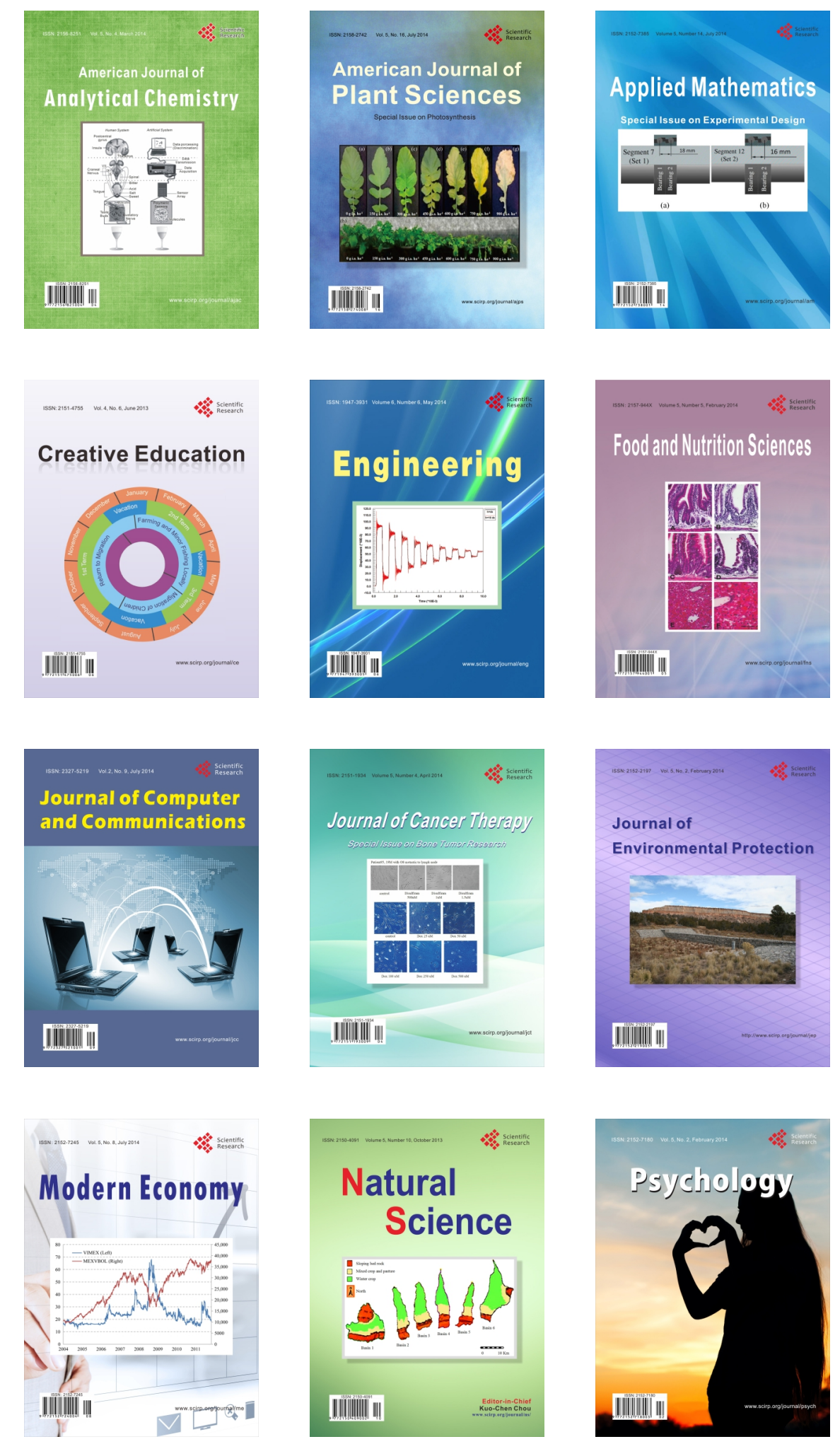